\title{
Assessing the Landscape Value of Public Works: Validation of the Methods in the Lowlands of the Middle Section of the Tajo River, Spain
}

\author{
ANA BELÉN BERROCAL MENÁRGUEZ: \\ PEDRO MOLINA HOLGADO
}

\begin{abstract}
This paper proposes a method of landscape characterisation and assessment of public works associated with fluvial landscapes, which is validated in the middle section of the Tajo River. In this method, a set of criteria is identified that unifies various characteristics of the landscape associated to the infrastructures. A specific weight is then assigned to each criterion in such a way as to produce a semi-quantitative value ranging from a minimum value of 0 to a maximum value of 10. Taken together, these criteria enable us to describe and assess the value of the public works selected for study, in this case helping us to evaluate the sections of the River Tajo analysed in our study area. Accordingly, the value of all the infrastructures associated to a stretch of the river covering several hundred kilometres was determined and after dividing this stretch into sections, they were compared under equivalent conditions to provide a hierarchal ranking.
\end{abstract}

KEY WORDS: Landscape, public works, landscape assessment, Tajo, rivers

\section{Introduction}

The human imprint on the landscape is so ingrained that it is generally difficult to dissociate natural elements from built elements. This closely tied mix of natural spontaneity and human will has produced landscapes dominated by either natural or cultural features, spatial compositions whose interpretation requires a profound understanding of the existing relationships between culture and nature. "Each civilisation has fashioned its own landscapes through an historic accumulation of identifiable contributions, each charged with cultural meaning, under which we find the persistent weave of nature" (Martínez de Pisón, 2001, p. 170). Landscape is therefore the complex, holistic, concrete and tangible expression of the relationship that mankind has had with nature in space and through the ages (Antrop, 2005; Carapinha, 2009; Martínez de Pisón, 2009), with science and emotion also 
participating in its creation (Ortega Cantero, 2008). It is also a clear sensory, perceptual, aesthetic and artistic experience (Mata Olmo, 2006; Renes, 2009; SauleSorbé, 2006), deeply connected to processes that constitute historical memory and national identity (Ortega Cantero, 2005).

Landscape is much more than a physical reality; it embodies psychological, social and cultural mores (Palang et al., 2005). Landscapes associated with water possess their own distinguishing features and values with respect to other spaces. Water determines the spatial connectivity of these spaces, and it is in this sense that it becomes the main natural agent that structures life and the way in which the land is used (Horden \& Purcell, 2001), as readily seen in ancient civilisations and traditional cultures (Granero Martín, 2008; Laureano, 2005).

Any attempt to interpret landscape requires an understanding of each of its parts and therefore, it would seem fitting to analyse the landscape dimension associated to public works. It is important to understand the way in which these human constructions participate in the genesis of the landscape and, indeed, acknowledge the wealth and value of this heritage as suggested in the report drafted by the Observatory of Sustainability in Spain regarding the natural, cultural and landscape heritage (Jiménez Herrero, 2009). The European Landscape Convention, signed in Florence in 2000, also stresses the importance of management and protection of European landscapes, calling for the creation of tools to characterise and assess them (Ministerio de Medio Ambiente, 2008), as already undertaken in Spain on a smaller scale (Mata Olmo \& Sanz Herráiz, 2004).

It is in this context, albeit at a larger scale and restricted to specific elements rather than to the landscape as a whole, that we have situated this study. Its principal aim is to assess the value of the landscape dimension of public works as formal structures, as well as the importance of specific and clearly demarcated landscapes as a function of the qualities of the structures they contain, thereby providing a definitive assessment of the elements that constitute a landscape with a tangible historic heritage (Santacana \& Serrat, 2008). Importantly, it was not the aim of this study to analyse the subjective and symbolic nuances of these significant elements, in the sense suggested by the work of Silva (2009) that brought together contributions from various authors regarding these issues.

This method is proposed for its intrinsic interest, as a means to better understand landscapes, as well as for its potential use as a land management tool. It is derived from our previous work (Berrocal, 2010) and is used to analyse the fluvial landscapes of the River Tajo in the provinces of Guadalajara, Madrid and Toledo (central Spain). This geographic demarcation has been determined by the characteristics of this study, which is exclusively dedicated to the fluvial channels, banks and valleys of the upper and middle basin of the River Tajo (Figure 1).

The connection between this work and others dealing with river landscapes also responds to the need to validate the proposed methodology in an authentic setting, large enough to provide an extensive, representative and heterogeneous sample of public works suitable for analysis. At the same time, we have chosen this area for its specific and homogeneous characteristics, which can be considered a common and unifying context for all the structures studied.

As an area of study, the River Tajo valley possesses both of these characteristics. As the natural boundary of the Marca Media (or Middle March, as this central area was 


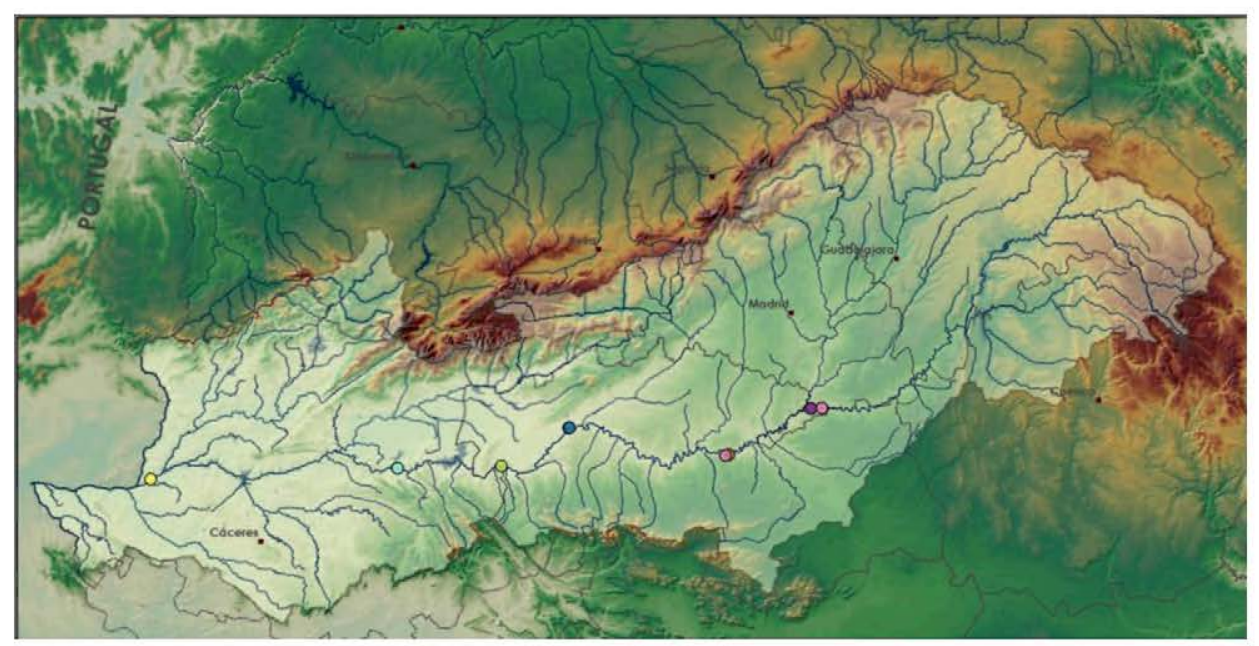

Figure 1. Map of the area.

known under Moorish rule), its historic evolution, and therefore the general planning of this territory, can be considered to have been homogeneous along the length of the river valley, save for a few locations or singular historical events. The east-west course of this fluvial depression also represented an obstacle to communications between the north and south of the peninsula, requiring the construction and maintenance of various means of river crossings throughout history, especially in the late Middle Ages, in the form of bridges, boats and fords, as in many other parts of the Iberian Peninsula (Medrano, 2008). This ensures a diverse set of structures and forms, and hence, a sample sufficiently heterogeneous for our proposed aims.

\section{Method Used in the Assessment of Public Works Associated to River Landscapes}

The method we propose does not intend to quantitatively assess the intrinsic value of the structures solely as heritage goods but rather, it aims to identify the attributes they convey to the river landscape in which they are located and to assess the increase or decrease in landscape value associated with their presence in this particular setting. This assessment integrates a set of diverse criteria based on a visual appreciation of the landscapes, as well as on the cognitive or conceptual aspects of the structures that explain their existence and configuration, in addition to their socio-historic value as examples of public infrastructures in the service of society (Figure 2). Insofar as landscape in general and river landscapes in particular represent a synthesis of nature and culture, an appreciation of civil engineering works and architecture as elements of a landscape must involve factors of an aesthetic nature, as well as other factors, no less significant, that are related to their historical, cultural and functional value.

This method is integrated into another more extensive technique (Molina Holgado \& Berrocal Menárguez, 2010) that is used to classify, characterise and assess Iberian fluvial landscapes that was developed on the basis of our earlier studies (Molina Holgado, 2007; Molina Holgado \& Berrocal Menárguez, 2006a). 
Table 1. Criteria used in the assessment of public work landscapes

\begin{tabular}{ll}
\hline Integration & $\begin{array}{l}\text { Use of local materials } \\
\text { Respect for surroundings }\end{array}$ \\
& $\begin{array}{l}\text { Respect for natural landmarks } \\
\text { Respect for historical landmarks } \\
\text { Adaptation to land }\end{array}$ \\
Value & $\begin{array}{l}\text { Scale in keeping with that of surroundings } \\
\text { Technical innovation within historical context } \\
\text { Stylistic representativeness } \\
\text { Social importance of the structure within its historical } \\
\text { context } \\
\text { Abundance-uniqueness }\end{array}$ \\
& $\begin{array}{l}\text { General state of conservation } \\
\text { Degree of representativeness of prior restoration } \\
\text { Impact of recent restoration }\end{array}$ \\
Conservation & $\begin{array}{l}\text { Scale appropriate to its function } \\
\text { Aesthetic resolution of technical problems }\end{array}$ \\
Technical-aesthetic coherence & Symbolic value
\end{tabular}

Phase 1: Identify value assessment criteria (5) and sub-criteria (14)

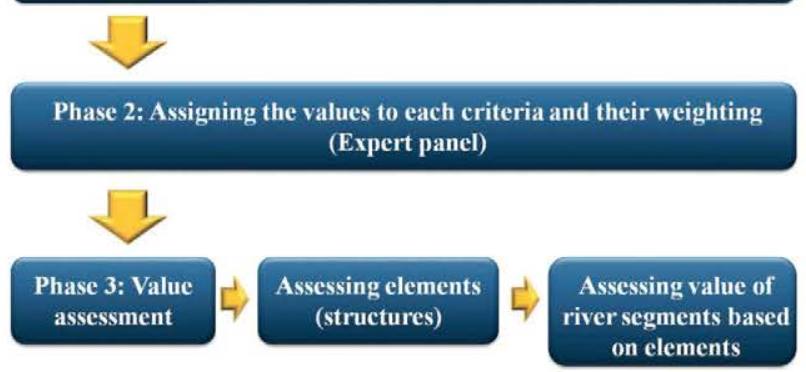

Figure 2. General diagram showing value assessment method.

It is also associated with methods proposed in various studies that have established taxonomies to be used in the characterisation and assessment of river systems in Spain, and which mostly follow the requirements set forth in the Water Framework Directive (González del Tánago \& García de Jalón, 2006; González del Tánago et al., 2006; Munné et al., 1998; Suárez \& Vidal-Abarca, 2000; Suárez et al., 2002), along with other methods to evaluate architectural elements (Fuentes, 2010).

\section{Description of the Criteria Used in the Assessment}

\section{Integration within Landscape}

Use of local materials. The use of construction materials, especially stone, taken from the structure's surroundings, favours its integration within the landscape. By 
contrast, the use of exogenous materials would require an effort to visually reconcile the structure with its surroundings, a task that may be difficult at times. Nevertheless, these drawbacks can be mitigated by choosing foreign materials with textures and colours that blend well with the surroundings. This item, therefore, takes into consideration the extent to which the materials employed in the construction of the structure are aesthetically consistent with surrounding scenery.

\section{Respect for surroundings}

This criterion assesses the extent to which the structure adapts to its physical surroundings. This includes the sensitivity with which the builder, engineer or architect creates a structure whose design and features conform to the peculiarities of its surroundings, putting technical know-how and creativity at the service of landscape beauty and harmony. This respect for built landscapes is assessed bearing in mind three aspects:

- Respect for natural landmarks: this is the extent to which natural elements are taken into consideration when choosing a design or style of construction for the structure, even in situations where this consideration is not based on aesthetic principles. For example, positioning bridge piers on river banks to minimise main channel obstruction or on mid-channel islands usually respond to factors that are purely technical. Regardless of whether or not this decision is taken for aesthetic motives, the final result is a structure in harmony with the river landscape that will be positively evaluated.

- Respect for historical landmarks: assessing historical constructions is a relatively recent phenomenon in our culture. Until recently it wasn't uncommon for historical structures to suffer some sort of damage, either during restoration activities that removed valuable architectural elements or through the mining of stone from heritage structures for use in new projects, or even for secondary or private buildings (homes, sheds, etc.). Damage to existing historical sites can also result from structures that are associated with river systems, mainly dams and the smaller azudes (or diversion dams), that flood both smaller and larger areas upstream, on occasions inundating valuable structures. Pre-existing structures are also overshadowed by other exclusionary architectures, the latter featuring architectural designs that visually dominate the landscape and prevent the spectator from viewing nearby historical structures that are either completely obstructed or dominated by the newer constructions.

- Adaptation to land: this item takes into account the surrounding area's role in supporting and driving civil engineering design. In the past, structures were designed on the basis of topographical features of the area, which not only represented the context in which construction took place but that also conditioned the type of construction used. Apart from the unquestionable improvements in construction, technological advances have helped to break the connection between land and man-made works. The structures we build are no longer at the service of the terrain, and now it is the land which must conform to the construction design, type and specific velocities. Tunnels, clearings, embankments, viaducts, as well as the dredging and filling required in their 
construction, dissociate the resulting structures from the land. Thus, standard bridges, standard roads and no end of standard structures appear to be cut-off from their surroundings. The idea of place is no longer of any importance at all and the landscape is rendered mundane.

\section{Scale in keeping with that of surroundings}

In close association with the previous section, this aspect examines the issue of the scale of the structure with regard to its physical surroundings. Magnificent landscapes can accommodate larger dimensions owing to their powerful volumes, yet flat or slightly undulating landscapes require less bulky structures. At times, a contrast in form and volume may give rise to aesthetically suggestive results. In this sense, dams which collect large volumes of water are often given as examples of colossal, unaesthetic volumes yet the magnificence of these same volumes do not always mean a dissociation of the structure from the terrain in terms of local scale. An example of this is the 140 metre-high Aldeadávila Dam, which is perfectly integrated within the granite surroundings of the Arribes del Duero.

\section{Historical value}

The historical value takes into account the aesthetic importance given to a landscape built by virtue of our knowledge of its past. "When we become aware of the meaning [of a built landscape] forged by the passing of time, we see it in another light, enjoying it to the utmost degree" (Aguiló, 1999, p. 32). Determining this value requires prior knowledge of the work, its history and the techniques used in its construction.

The items described in this section represent an attempt to extract the principal characteristics that define the historical value of the structure and that are closely related to its aesthetics.

Age. The age of an historical work does not have an intrinsic value, yet it does hold a value in the collective consciousness of society, whose body of knowledge is built upon the previously acquired knowledge of its ancestors. It is this social consciousness which lends a value to age. Historical or pre-historic works speak of our species, they tell us how our ancestors saw their environment, its landscape, how they transformed it, how they learned to live in it and live off it. In addition, they also tell us about our future and make us aware of the transience of humans as individuals but also, they define the enormous power of our society to perpetuate itself, through its landscapes and structures.

Technical innovation within historical context. The aesthetics of public works are intimately tied to technical innovation and advances in materials. Thus, technical innovation in the works studied is a value that must be assessed as it is an inextricable part of the works themselves, contributing an interesting aesthetic element.

Stylistic representativeness. This item values whether the style of a work is representative of the prevailing styles in its historical context. From an artistic 
standpoint, this criterion is very important because it helps to define stylistic and structural characteristics that are representative of a particular period in history. Additionally, the heritage value of a work that was built in the style of the period is greater than those which were not.

Social importance of the structure within its historical context. Public works associated to river landscapes have traditionally fulfilled the following functions: to enable communication between opposite banks (bridges, boat crossings, fords, etc.); to provide water to towns or agricultural areas (canals and dams); and to utilise the river current as a driving force for other activities (watermills, river transport, etc.). The strategic importance of these functions often reflected the economic level of a particular region, the human means that were available for its construction, and the scale of the work, that is, its monumentality. All of these aspects represent the economic prosperity of the period. A good example of this is the Camino Real de Toledo, a road linking the city to Madrid, whose importance grew enormously during the fifteenth century. The economic importance of this roadway went beyond the local scale as it was just a small part of the intricate network of roads connecting the north to the south and eastern lands to the Iberian Peninsula (Puñal Fernández, 1994).

Abundance-uniqueness. Regardless of other values attributable to a work that are representative of a particular architectural style or that date from a specific time period, the scarcity of works in a particular style or period in a given region could make the work unique and therefore valuable from a heritage standpoint. Its uniqueness is internalised by the spectator as an added value of the work with respect to its setting.

\section{Conservation}

This criterion constitutes the physical condition of the public works as landscape elements. These conditions depend on the age of the work, its state of conservation and the repairs it has undergone throughout its history. The items contained in this section are the following.

General state of conservation. The state of conservation directly influences the aesthetic qualities of the work and as a result, its quality as a landscape element. However, a poorly conserved work or a structure in ruins does not necessarily imply a loss of landscape value: the Romantic movement placed a high aesthetic value on monuments eroded by the passing of time and these ruins provided them with the poetics that would inspire some of the art of the era. "Greatly deteriorated monuments were highly valued, as well as those that had been partially destroyed and that blended into their natural setting to form an indivisible whole" (Hernando, 2004, p. 281). It is necessary at this point to distinguish between the aesthetic value that a given historical public structure in ruins may attain in a given landscape (Saule-Sorbé, 2008) and the moral responsibility of a society in general, and public administration in particular, to restore or at least reinforce the structure in question. 
Impact of recent restoration. The first restoration projects undertaken in Europe in the nineteenth century focused on strengthening a structure in ruins by incorporating retaining elements that were quite different from the original materials and style, to avoid any confusion regarding the chronological age of modern elements. When necessary, reconstruction of architectural elements (walls, balustrades, etc.) was not undertaken with a view to imitate the original style. A great number of current restoration experts have inherited this methodological approach, "opting to intervene on the monument with a two-fold aim: first, to slow down further deterioration and second, to regenerate it" (Hernando, 2004, p. 282). Another controversial technique arose in the nineteenth century, although it was not often employed in Spain, known as exclusivistic Romanticism which removed remains that were added during later time periods, in some cases reaching purist extremes and recreating parts that had never existed.

Therefore, assessing the value of present-day repairs and restoration is not entirely immune to interpretation. Nevertheless, for our method of assessment we will apply a guiding parameter based on the respect for the work in terms of its structure, composition and colour. We will not, a priori, consider the addition of modern architectural elements used as restorative auxiliary structures to be detrimental to the value of a work, although they should meet some standards associated to consistency in terms of colour and form with respect to the work that is to be restored. Furthermore, although all items will be assessed by a team of experts in the field, this particular issue takes on a special relevance owing to a certain degree of methodological disparity.

Degree of representativeness of prior restoration. In keeping with the exclusivistic Romanticism mentioned above, some experts from the field of art, archaeology, architecture and engineering reject later incorporations into classical public works, arguing that these additions are often disconnected from the original architectural structure. In effect, historical repairs and restoration of classic works were not usually undertaken following criteria that called for stylistic conciliation, rather their sole aim was functional and at any rate, exclusively applying to contemporary architectural criteria. The action of time on these appendages has contributed to their later integration within the work itself and their aesthetic value as unique elements unto themselves, mitigating the criticism towards these interventions. This is why we have chosen to differentiate historical repairs from recent restorations, thereby creating two independent items for assessment.

\section{Technical-aesthetic coherence}

Public works exist because they satisfy human needs and thus, they are generally eminently practical structures. Nevertheless, their design has usually followed specific aesthetic guidelines, save for some historical periods. Furthermore, for centuries the techniques available were usually conditioned by the materials known to builders, mainly wood and stone, and in other latitudes, vegetable fibres. With the arrival of cement and iron after the Industrial Revolution, the technical possibilities for construction multiplied, and there was an additional and urgent demand for infrastructures on the part of a burgeoning population. The need for rapid and easy 
execution of public works relegated aesthetics to a secondary plane (Molada Gómez, 1996). It is from this moment onwards that the definitive split between architecture and engineering took place, the latter dominating the philosophy behind the majority of public service works, which in the fluvial environment meant bridges, canals, dams and other structures. It would subsequently be engineering and not architecture that would determine the future of the newly built river landscapes.

During the eighteenth and nineteenth centuries, techniques would gradually cease to be at the service of construction materials and an inverse relationship of dependence was to develop, especially during the twentieth century. It is no surprise that at the inaugural sessions of the Real Academia de Bellas Artes de San Fernando (2004), Elices Calafat declared in his speech entitled 'Los Gozos y las formas (or Pleasure and Form): Previously, material dictated form, but from now on form will dictate material.' This freedom in construction, far from facilitating the task of the designer, "obscures the path to a formal solution, precisely because it has become simpler. It's like water: if it lacks a well-hewn channel it will flood surrounding land aimlessly, with no clear destination" (Fernández Ordoñez, 1990, p. 52).

Scale appropriate to its function. On occasion, in his or her zeal to create a great work, the designer distances him or herself from the functional purpose of the original task. Height, distance, light and slenderness have always challenged builders, who are often financially backed by those promoting the work (royalty, nobility, military, the state, municipalities, private citizens, etc.). Thus, if given the opportunity, they often ran the risk of designing structures that were over-sized, exaggerated and pretentious, ignoring the tenet of "form in keeping with material" that reflects the "logic of form" (Torroja Miret, 1960), and adding superfluous elements that weighed down the structure with unnecessary ornament. Although its design was driven by aspirations unrelated to ostentation, the Entrepeñas-Buendía hydraulic system is a good example of a structure whose scale far exceeds its function and above all, that is disproportionate to its fluvial context (Díaz Marta, 1995; Molina Holgado \& Berrocal Menárguez, 2006b).

Aesthetic resolution of technical problems. The history of construction has provided us with astonishing examples of triumphs over technical problems and feats of ingenuity loaded with aesthetic appeal. Early Roman bridges were built with pylons that were as wide as the span of the arches they supported. The resulting increase in resistance to water flow would cause these structures to collapse whenever there was a significant rise in river water levels. This problem was solved with the addition of flood openings in the tympana, which allowed the passage of water, lessening its force upon the structure during flooding. This example of ingenuity not only solved a serious problem but also lightened the work aesthetically. Another example can be found in the large rail viaducts built at the end of the nineteenth century. The lighter weight of steel with respect to the stone that was traditionally employed made the pylons more vulnerable to the force of the wind, which behaved like corbels. The first solution to this problem was the building of mixed material piers, that is stone at their base and metal employed in the rest of the bridge. The stone bases gradually diminished in successive structures, culminating in the work of engineer Gustave Eiffel, whose pylon design employed iron alone and was also 
resistant to the wind, a feat immortalised in the tower that bears his name (Fernández Casado, 1977). The arrangement, form and curvature of its iron latticework fulfil specific structural requirements but overall, what comes across is the structure's exceptional aesthetic quality.

This item, therefore, assesses the contributions made by technique to the aesthetics in each of the works studied, either intentionally or otherwise.

\section{Symbolic value}

The collective unconscious, especially in traditional rural societies, contains many images in which water possesses special symbolic value (Arroyo Ilera, 1998). The images in which water is shown as a natural resource are of particular interest to this study because this is where we see works of river engineering being used as symbols. Additionally, the traditional image of water as a dangerous force has linked works of hydraulic ingenuity to an interesting popular culture that bestows them with a quasi-magical quality. This is especially true for bridges, as they were considered to be veritable acts of defiance against the forces of nature.

Oral popular culture is rife with sayings, proverbs and songs about works of river engineering. Poetry too, has incorporated these structures as part of its repertoire and the iconographic value of public works in river landscapes is evident on many occasions. The image of a bridge, mill or dam has often been used as an emblem representing the identity of a group.

This item represents the symbolic value of the works studied, taken as added value to their status as landscapes.

\section{Assessing the Value of the Works Studied}

We assessed the value of the public works in our study by assigning a score to each criterion under consideration. To simplify the method, the scores are reduced to five possible values: 0 (very low), 1 (low), medium (2), high (3), very high (4). We considered that the contribution of each criterion to the value of the landscape is not homogeneous and so these were weighted, limiting weights to four possible values $(0.25,0.50,0.70$ and 1) that attributed them greater or lesser importance. These weights were determined by a panel of professional experts from various fields (engineering, geography, architecture, history, fine art) and distributed among the various criteria (Table 2).

The criteria were selected by the authors having first consulted experts in these areas as to the appropriate criteria to employ. Nevertheless, the aim was to select criteria adapted to the reality of the public works, as well as to the characteristics of the cultural and natural contexts, and the landscape in which they are found. All the experts consulted were university researchers or professionals associated with the research topic, and the selection of the evaluation criteria was approved by the experts.

Weighting the importance of the criteria was performed as follows:

A. Once the criteria for valuation were accepted, each expert indicated the importance of each criterion by awarding it a value between 0 and 4 .

B. The authors received the valuation from the different experts and they then sent the results of the valuations of all the members of the panel to each expert 
Table 2. Weighting of value assessment criteria

\begin{tabular}{|c|c|c|c|}
\hline \multicolumn{3}{|c|}{ Value assessment criteria for river engineering works in their landscapes } & Weight \\
\hline $\begin{array}{l}\text { Integration within } \\
\text { its landscape }\end{array}$ & $\begin{array}{l}\text { Use of local materials } \\
\text { Respect for surroundings } \\
\text { Scale in keeping with that }\end{array}$ & $\begin{array}{l}\text { Respect for natural landmarks } \\
\text { Respect for historical landmarks } \\
\text { Adaptation to land } \\
\text { of surroundings }\end{array}$ & $\begin{array}{l}1 \\
0.75 \\
0.75 \\
0.75 \\
1.00\end{array}$ \\
\hline Historical value & $\begin{array}{l}\text { Age } \\
\text { Technical innovation with } \\
\text { Stylistic representativeness } \\
\text { Social importance of the s } \\
\text { historical context } \\
\text { Abundance-uniqueness }\end{array}$ & $\begin{array}{l}\text { n historical context } \\
\text { ructure within its }\end{array}$ & $\begin{array}{l}0.50 \\
0.25 \\
0.25 \\
0.25 \\
0.50\end{array}$ \\
\hline Conservation & $\begin{array}{l}\text { General state of conservat } \\
\text { Degree of representativene } \\
\text { Impact of recent restoratic }\end{array}$ & $\begin{array}{l}\text { on } \\
\text { ss of prior restoration } \\
\text { n }\end{array}$ & $\begin{array}{l}1.00 \\
0.25 \\
0.75\end{array}$ \\
\hline $\begin{array}{l}\text { Technical-aesthetic } \\
\text { coherence }\end{array}$ & $\begin{array}{l}\text { Scale appropriate to its fu } \\
\text { Aesthetic resolution of tec }\end{array}$ & $\begin{array}{l}\text { iction } \\
\text { inical problems }\end{array}$ & $\begin{array}{l}0.25 \\
0.50\end{array}$ \\
\hline Symbolic value & Symbolic value & & 0.50 \\
\hline
\end{tabular}

without indicating their source. Accordingly, a second valuation was requested from each expert in case they considered it necessary to modify their original evaluation.

C. The experts finally sent the valuation to the authors so that the final valuation could be established, taking into account the opinions from this second round of evaluation.

The landscape value of a work is therefore defined by the expression:

$$
V=\sum_{i}\left(p_{i} \cdot V_{i}\right)
$$

$p_{i}$ and $V_{i}$ being the pre-defined weight and the value given to each criterion respectively.

For a decimal value $V_{d}$ (from 0 to 10 ), the $V$ above must be used in the following way:

$$
V_{d}=\left(V-V_{\min }\right) \cdot 10 /\left(V_{\max }-V_{\min }\right)
$$

With $V_{\min }$ being the lowest possible value of $V$; in this case, $V_{\min }=0$ and $V_{\max }$ represents the greatest value, that is, $V \max =37$. By substituting these values we obtain the following:

$$
V_{d}=V \cdot 10 / 37
$$

or:

$$
V_{d}=0.27 \cdot V
$$


Therefore the structure in question receives a landscape value on a decimal scale, so it should be graded on a range of values from 0 to 10 , but which for the sake of simplicity has been reduced to five (Table 3).

\section{Assessing the Value of Fluvial Sections}

The value of specific areas was assessed using the landscape value that was determined for each of the works studied. To prevent the distortion of value that

Table 3. Quantitative and qualitative scales and the correspondence between them

\begin{tabular}{lcccc}
\hline Very low & Low & Medium & High & Very high \\
\hline$<2$ & {$[2,4)$} & {$[4,6)$} & {$[6,8)$} & $\geq 8$ \\
\hline
\end{tabular}

Table 4. Values of a river section

If the section contains one work: $\mathrm{V}_{\text {section }}=\mathrm{V}_{\text {work }}$

If the section contains more than one work, then

When at least $50 \%$ of the works have a $\mathrm{V}_{\text {WORK }} \geq 5$, then:

$$
\mathrm{V}_{\text {section }}=\max \mathrm{V}_{\text {work }}
$$

When at least $50 \%$ of the works have $\mathrm{V}_{\text {WORK }}<5$, then:

$$
\mathrm{V}_{\text {section }}=\text { average } \mathrm{V}_{\text {work }}
$$

Table 5. Distribution of the works studied, by river section

River section (length of channel in $\mathrm{km}$, province)

Section 1. Villamanrique de Tajo-El Embocador Dam (25.69 km, MadridToledo)

Section 2. El Embocador Dam-Jarama River (13.5 km, Madrid)

Section 3. Toledo-Municipality $(9.41 \mathrm{~km}$, Toledo)

Section 4. Mouth of Alberche RiverAzután Reservoir $(17.76 \mathrm{~km}$, Toledo)

Section 5. Arzobispo Bridge-Valdecañas Reservoir (3.73 km, Toledo-Cáceres) Section 6. Valdecañas Reservoir-Torrejón Reservoir (3.74 km, Cáceres)

Section 7. Alcántara Reservoir-Cedillo Reservoir (14.1 km, Cáceres)
Works studied

El Embocador Dam (Municipality of Aranjuez, Madrid)

Aranjuez Area (Municipality of Aranjuez, Madrid)

Alcántara Bridge (Municipality of Toledo)

San Martín Bridge (Municipality of Toledo)

Puente Viejo Bridge (Municipality of Talavera de la Reina, Toledo)

Puente de Hierro Bridge (Municipality of Talavera de la Reina, Toledo)

Puente del Arzobispo (Municipality of Puente del Arzobispo, Toledo)

Almaraz Bridge (Municipality of Almaraz, Cáceres)

Alcántara Bridge (Municipality of Alcántara, Cáceres) 
Table 6. Assessment of landscape value of work

\begin{tabular}{|c|c|c|c|c|}
\hline & & Weight & Value given & Weighted value \\
\hline Integration & $\begin{array}{ll}\begin{array}{l}\text { Use of local materials } \\
\text { Respect for surroundings }\end{array} & \begin{array}{l}\text { Respect for natural landmarks } \\
\text { Respect for historical landmarks } \\
\text { Adaptation to land }\end{array} \\
\text { Scale in keeping with that of surroundings }\end{array}$ & $\begin{array}{l}1.00 \\
0.75 \\
0.75 \\
0.75 \\
1.00\end{array}$ & $\begin{array}{l}3 \\
4 \\
4 \\
3 \\
3\end{array}$ & $\begin{array}{l}3 \\
3 \\
3 \\
2.25 \\
3\end{array}$ \\
\hline Historical & $\begin{array}{l}\text { Age } \\
\text { Technical innovation within historical context } \\
\text { Stylistic representativeness } \\
\text { Social importance of the structure within its historical context } \\
\text { Abundance-uniqueness }\end{array}$ & $\begin{array}{l}0.50 \\
0.25 \\
0.25 \\
0.25 \\
0.50\end{array}$ & $\begin{array}{l}2 \\
4 \\
4 \\
4 \\
3\end{array}$ & $\begin{array}{l}1 \\
1 \\
1 \\
1 \\
1.5\end{array}$ \\
\hline Conservation & $\begin{array}{l}\text { General state of conservation } \\
\text { Degree of representativeness of prior restoration } \\
\text { Impact of recent restoration }\end{array}$ & $\begin{array}{l}1.00 \\
0.25 \\
0.75\end{array}$ & $\begin{array}{l}4 \\
4 \\
4\end{array}$ & $\begin{array}{l}4 \\
1 \\
3\end{array}$ \\
\hline Technical-aesthetic coherence & $\begin{array}{l}\text { Scale appropriate to its function } \\
\text { Aesthetic resolution of technical problems }\end{array}$ & $\begin{array}{l}0.25 \\
0.50\end{array}$ & $\begin{array}{l}4 \\
4\end{array}$ & $\begin{array}{l}1 \\
2\end{array}$ \\
\hline Symbolic value & Symbolic value & $\begin{array}{c}\quad 0.50 \\
V=\sum i\left(p i^{*} V i\right) \\
\mathrm{V} 10 \text { work }\end{array}$ & 2 & $\begin{array}{l}31.75 \\
8.58\end{array}$ \\
\hline
\end{tabular}



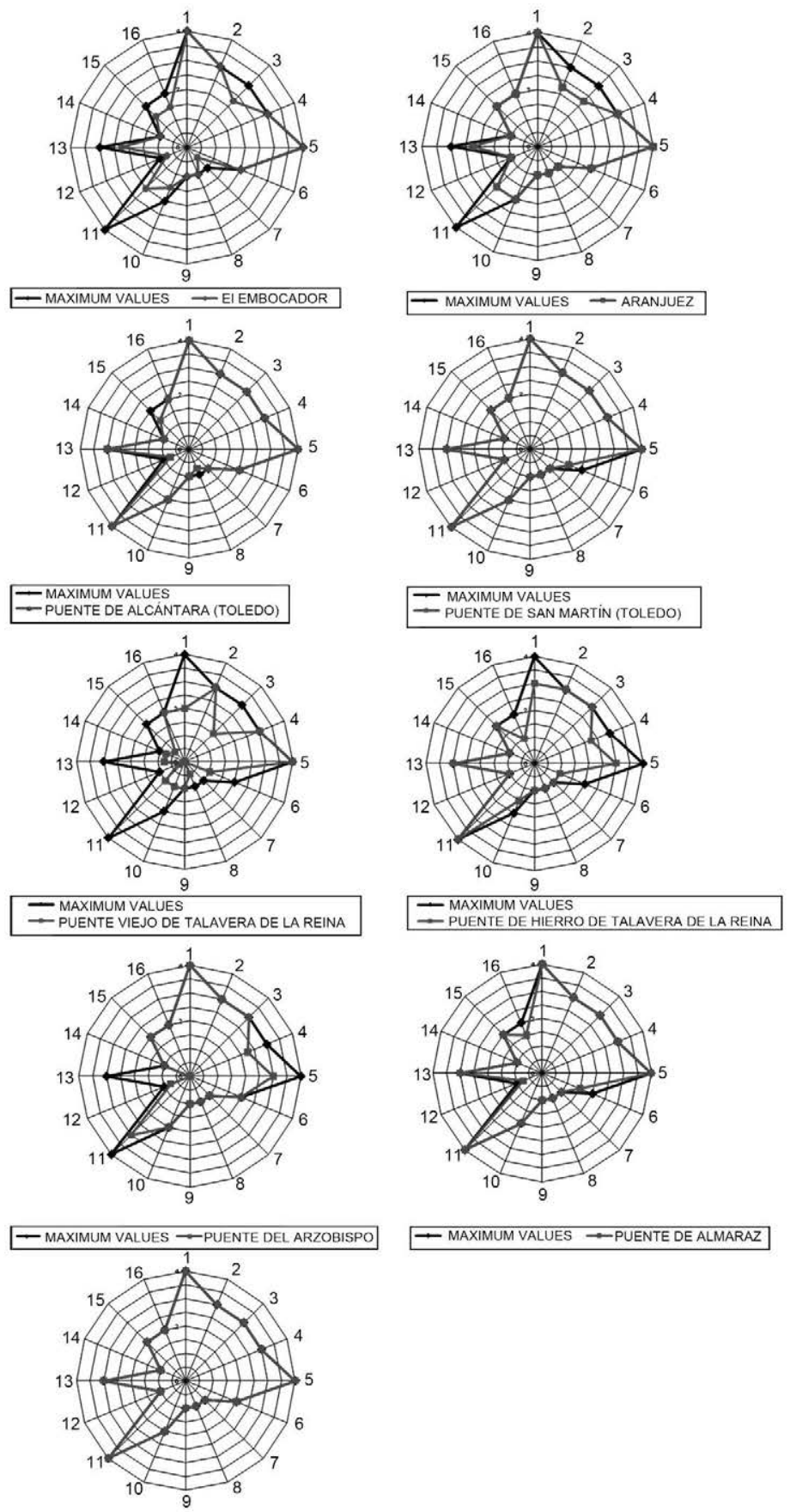

$\rightarrow$ MAXIMUM VALUES $\rightarrow$ PUENTE DE ALCÁNTARA

Figure 3. Assessment values according to the assessment items. Works from left to right and top to bottom: 'El Embocador' Dam; Municipality of Aranjuez; Alcántara Bridge (Toledo); San Martín Bridge (Toledo); Puente Viejo Bridge (Talavera de la Reina); Puente de Hierro Bridge (Talavera de la Reina); Puente de Arzobispo Bridge; Almaraz Bridge; Alcántara Bridge. 
would occur by combining values of an exceptional work with others of a lesser value, we discarded the arithmetic average. To avoid this type of distortion, we applied the criteria described in Table 4 . We believe that through this approach, we will obtain a value for the section that corresponds more closely to that perceived by a knowledgeable spectator.

\section{Results}

To apply this method we selected a number of river engineering works found in the middle segment of the River Tajo and the segment running through the Aranjuez municipality. This section of the river features a high density of engineering works that are so closely associated to their fluvial environment that they cannot be considered in isolation. The distribution of works studied along the various sections that make up the study area is indicated in Table 5. The application of this assessment method to a specific civil work is shown in Table 6, in this case the Puente de Hierro (bridge) in Talavera de la Reina.

The results we obtained, that is, the assessment values for each item, are shown in the form of star charts (Figure 3), as well as in a table containing the final qualitative and quantitative assessment for each of the works, as well as an assessment of the river sections (Table 7).

The chart axes show the assessment items: 1 . Use of local materials; 2 . Respect for natural landmarks; 3. Respect for historical landmarks; 4. Adaptation to the landscape; 5. Scale inkeeping with that of surroundings; 6. Age; 7. Technical innovation within the historical context; 8 . Representative style; 9. Social importance of the structure within its historical context; 10. Abundance-uniqueness; 11. General state of conservation; 12 . Degree of representativity of prior restoration; 13. Impact of recent restoration; 14. Scale appropriate to its function; 15 . Aesthetic resolution of technical problems; and 16. Symbolic value.

As can be observed in the results shown in Figure 3, there is a strong correlation between the maximum values and the values given to each of the works in every case $\left(r_{s}>+0.8, p<0.05, n=16\right)$. This proximity between both values is mainly due to the high quality of the works studied, whose overall average value is high and with a low dispersion value $(8.84 \pm 1.2, n=9)$. In keeping with the criteria applied to assess the river sections (Table 4), the evaluation of each of the seven

Table 7. Final assessment: works

\begin{tabular}{lcc}
\hline Civil work & Value $0-10$ & Qualitative value \\
\hline El Embocador dam & 8.45 & Very high \\
Real Sitio de Aranjuez & 8.85 & Very high \\
Alcántara bridge of Toledo & 9.73 & Very high \\
San Martín bridge & 9.86 & Very high \\
Puente Viejo (bridge) of Talavera & 6.01 & High \\
Puente de Hierro (bridge) of Talavera & 8.58 & Very high \\
Arzobispo bridge & 8.38 & Very high \\
Almaraz bridge & 9.66 & Very high \\
Alcántara bridge & 10 & Very high \\
\hline
\end{tabular}




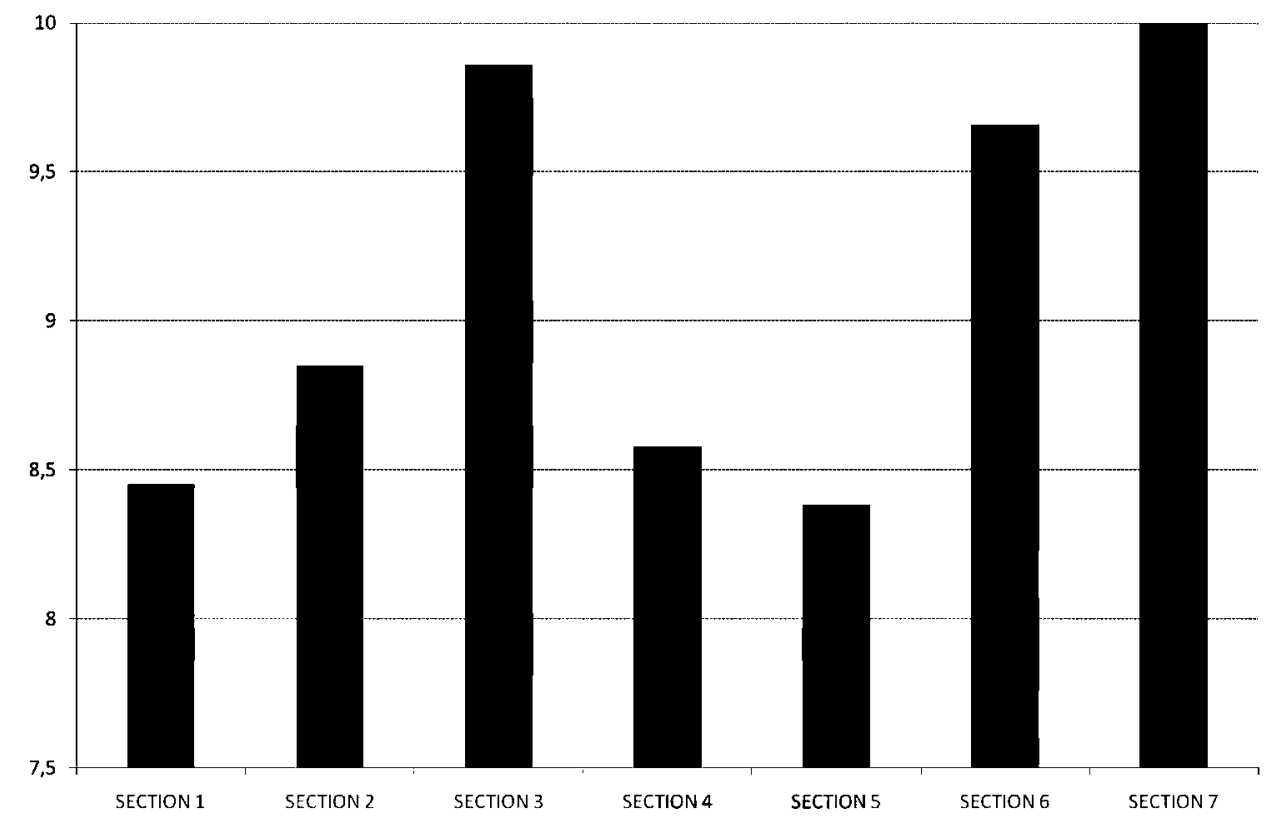

Figure 4. Final assessment: sections (x-axis: sections of the study area; y-axis: value 0-10).

sections analysed (Figure 4) is similarly high. Indeed, the minimum value was found to be 8.38 and the maximum value 10 , with an average value of $9.1( \pm 0.7$, $n=7$ ).

These values show the importance of the elements built in the River Tajo lowlands landscape. Consequently, they highlight the need for appropriate management of this cultural landscape, not only for its intrinsic value but also because it is an important part of the overall landscape heritage of this region.

\section{Conclusions}

There are many agreements and legal documents that refer to the need to protect our landscapes and heritage in all their varied forms. For example, in article 5d, The European Landscape Convention stresses the importance of "integrating landscape into regional and town planning and into cultural, environmental, agricultural, social and economic policies (...)". Furthermore, the UNESCO Convention Concerning the Protection of World Cultural and Natural Heritage calls for the identification, protection and preservation of heritage worldwide.

Public works are without doubt one of the most prominent landscape elements over large extensions in general, and in Spain in particular. The age-old and intense human occupation in this part of the Iberian territory, its diversity in terms of its morphostructural and cultural heterogeneity, in turn derived from its complex history, are quite possibly the main factors that explain the significance and abundance of these and other human interventions, and as a consequence, the diversity of Spanish landscapes. Public works are also important cultural resources that qualify their surrounding landscapes and for this reason, as cultural assets they represent a strategic 
element in terms of environmental and economic sustainability, in the sense referred to previously in various studies (Bedate et al., 2004; Mascari et al., 2009; Jiménez Herrero, 2007). Therefore, they are an essential part of any landscape as elements that not only create the landscape but also, that represent its material and intangible content. They also represent a dynamic part of the landscape, a characteristic associated with their function and status as a complex resource (cultural, heritage and economic).

For these reasons it seems especially appropriate to develop methods and techniques that offer us the opportunity to define and evaluate the quality and importance of some of the more relevant landscape elements, such as that proposed in this paper. In this specific case, we refer to the case of the civil engineering works associated with the landscapes of the River Tajo, one of the central Spanish axes in both environmental and historical terms.

The method of analysis developed in this paper allows us to gauge the landscape value of the civil engineering works within the study area. It does enable us to know the value of the sections where they are located. In each case, the engineering works that we study were graded over 8; a few sections even reached 9.5. All of them harbour important heritage pieces, related to water, possibly belonging to the tenth century or even before in Section 3, of the first half of the sixteenth century in Section 6 and the early second century in Section 7 (See Table 5 for locating Sections).

We must stress that the method of assessment proposed in our study focuses on both the landscape and the work itself. This dual focus extends to the valuation of the technical, construction and historical quality of each element as a material part of our heritage but also, to the integration of the work within its respective territorial and landscape context. The objective is to help understand these works as a part of their environment. In effect, to go beyond the all-too frequent work-monument association, without undermining the specific protection that any valuable structure should receive in function of its characteristics.

\section{References}

Aguiló, M. (1999) El Paisaje construido: una aproximación a la idea de Lugar (Madrid: CICCP).

Antrop, M. (2005) Why landscapes of the past are important for the future, Landscape and Urban Planning, 70(1-2), pp. 21-34.

Arroyo Ilera, F. (1998) La imagen del agua. Ideas y nociones hidrográficas en las Relaciones Topográficas de Felipe II, Revista de Arte, Geografia e Historia, 1, pp. 155-194.

Bedate, A., Herrero, L. C. \& Sanz, J. A. (2004) Economic valuation of the cultural heritage: Application to four case studies in Spain, Journal of Cultural Heritage, 5, pp. 101-110.

Berrocal, A. B. (2010) Obra pública y paisaje, in: C. Sanz \& R. Mata (Dir.) Aplicación del Atlas de los paisajes de España a la Cuenca Hidrográfica del Tajo. MMARM, Universidad Autónoma de Madrid (unpublished report).

Carapinha, A. (2009) Los tiempos del paisaje, in: J. Maderuelo (Dir.) Paisaje e Historia (Madrid: CDANAbada Editores).

Díaz Marta, M. (1995) Las obras hidráulicas en España (1st edn 1969) (Aranjuez: Doce Calles).

Elices Calafat, M. (2004) Los Gozos y las Formas. Reflexiones sobre la estética de las formas estructurales. Discurso inaugural del curso 2004, Real Academia de Bellas Artes de San Fernando.

Fernández Casado, C. (1977) Estética de las artes del ingeniero, Revista de obras Públicas, 3140, pp. 3-17.

Fernández Ordoñez, J. A. (1990) El pensamiento estético de los ingenieros. Funcionalidad y Belleza (Madrid: Real Academia de Bellas Artes de San Fernando).

Fuentes, J. M. (2010) Methodological bases for documenting and reusing vernacular farm architecture, Joumal of Cultural Heritage, 11(2), pp. 119-129. 
González Del Tánago, M. \& García De Jalón, D. (2006) Caracterización jerárquica de los ríos españoles. Propuesta de tipología de tramos fluviales para su clasificación atendiendo a la Directiva Marco del Agua, Limética, 25(3-4), pp. 81-98.

González Del Tánago, M., García De Jalón, D., Lara, F. \& Garilleti, F. (2006) Índice RQI para la valoración de las riberas fluviales en el contexto de la Directiva Marco del Agua, Ingeniería Civil, 143, pp. 97-108.

Granero Martín, F. (2008) Agua y territorio. Arquitectura y paisaje (Sevilla: Universidad de Sevilla).

Hernando, J. (2004) Arquitectura en España 1770-1900, 2nd edn (Madrid: Manuales Arte Cátedra).

Horden, P. \& Purcell, N. (2001) The Corrupting Sea (Oxford: Blackwell).

Jiménez Herrero, L. M. (dir.) (2007) Observatorio de la Sostenibilidad de España 2007 (Madrid: OSE).

Jiménez Herrero, L. M. (2009) Patrimonio natural, cultural y paisajístico. Claves para la sostenibilidad territorial. Observatorio de la Sostenibilidad en España; Ministerio de Medio Ambiente, Medio Rural y Marino; Fundación Biodiversidad; Fundación de la Universidad de Alcalá de Henares, Madrid.

Laureano, P. (2005) Atlas de agua. Los conocimientos tradicionales para combatir la desertificación (Barcelona: UNESCO-Laia Libros).

Martínez De Pisón, E. (2001) Paisaje y obras hidráulicas, in: Las Obras Hidráulicas en España, pp. 167-208 (Madrid: Dirección General de Obras Hidráulicas. Ministerio de Medio Ambiente).

Martínez de Pisón, E. (2009) Miradas sobre el paisaje (Madrid: Biblioteca Nueva).

Mascari, G. F., Mautone, M., Moltedo, L. \& Salonia, P. (2009) Landscape, heritage and culture, Journal of Cultural Heritage, 10, pp. 22-29.

Mata Olmo, R. (2006) Un concepto de paisaje para la gestión sostenible del territorio, in: R. Mata \& A. Tarroja (Coords.) El paisaje y la gestión del territorio. Criterios paisajísticos en la ordenación del territorio y el urbanismo, pp. 17-40 (Barcelona: Diputación de Barcelona).

Mata Olmo, R. \& Sanz Herráiz, C. (Dir.) (2004) Atlas de los Paisajes de España (Madrid: Centro de publicaciones del Ministerio de Medio Ambiente).

Medrano, V. (2008) Los ríos en las relaciones comerciales castellano-portuguesas al final de la Edad Media, in: $\mathrm{M}^{\circ}$ Isabel del Val \& O. Villanueva (Coords.) Musulmanes y cristianos frente al agua en las ciudades medievales, pp. 247-273 (Santander: Universidad de Cantabria).

Ministerio De Medio Ambiente (2008) Convenio Europeo del Paisaje. Textos y comentarios, Ministerio de Medio Ambiente.

Molada Gómez, A. (1996) Los materiales de construcción y el cambio estético: sobre la estética del hierro y el cemento. Actas del Primer Congreso Nacional de Historia de la construcción. Madrid.

Molina Holgado, P. (2007) Los paisajes fluviales de la ribera del Duero en la provincia de Soria. Fundación Duques de Soria. Soria (unpublished report).

Molina Holgado, P. \& Berrocal Menárguez, A. B. (2006a) Tipología de los paisajes fluviales de los cursos de la Sierra de Guadarrama en la Comunidad de Madrid. III Congreso de Ingeniería Civil, Territorio y Medio Ambiente, Madrid.

Molina Holgado, P. \& Berrocal Menárguez, A. B. (2006b) Los efectos ambientales de la regulación de los cursos de la cabecera de la cuenca del tajo: la reducción de los bosques aluviales del Tajo-Jarama. III Congreso de Ingeniería Civil, Territorio y Medio Ambiente, Madrid.

Molina Holgado, P. \& Berrocal Menárguez, A. B. (2010) Metodología para la caracterización de paisajes fluviales. Aplicación a la Cuenca Hidrográfica del Tajo (España central), Terra Plural, 4 (2), pp. 141162.

Munné, A., Solà, C. \& Prat, N. (1998) QBR: un índice rápido para la evaluación de la calidad de los ecosistemas de ribera, Tecnología del Agua, 175, pp. 20-37.

Ortega Cantero, N. (2005) Paisaje, historia y nación (a propósito del Tableau de la Géographie de la France, de Paul Vidal de La Blache), in: N. Ortega (Ed.) Paisaje, memoria histórica e identidad Nacional (Madrid: UAM Ediciones-Fundación Duques de Soria).

Ortega Cantero, N. (2008) Visiones históricas del paisaje: entre la ciencia y el sentimiento, in: E. Martínez de Pisón \& N. Ortega (Eds) La recuperación del paisaje (Madrid: UAM Ediciones-Fundación Duques de Soria).

Palang, H., Helmfrid, S., Antrop, M. \& Alumäe, H. (2005) Rural landscape: Past processes and future strategies, Landscape and Urban Planning, 70, pp. 3-8.

Puñal Fernández, T. (1994) El camino real de Toledo y las relaciones comerciales con el Concejo de Madrid, in: C. Segura Graíño (Dir.) Caminos y caminantes por las tierras del Madrid medieval (Madrid: Asociación cultural Al-Mudayna). 
Renes, J. (2009) Paisajes europeos: continuidad y transformaciones, in: J. Maderuelo (Dir.) Paisaje e Historia (Madrid: CDAN-Abada Editores).

Santacana, J. \& Serrat, N. (2008) La dimensión patrimonial del paisaje, in: J. Busquets \& A. Cortina (Eds) Gestión del paisaje. Manual de protección, gestión y ordenación del paisaje, pp. 201-220 (Barcelona: Ariel).

Saule-Sorbé, H. (2006) Ante la prueba del motivo artístico: algunas reflexiones sobre la observación en el arte del paisaje, in: N. Ortega (Ed.) Imágenes del paisaje (Madrid: UAM Ediciones-Fundación Duques de Soria).

Saule-Sorbé, H. (2008) Les valeurs du pittoresque: définitions, évolution, applications, in: E. Martínez de Pisón \& N. Ortega (Eds) La recuperación del paisaje (Madrid: UAM Ediciones-Fundación Duques de Soria).

Silva, R. (2009) Agricultura, paisaje y patrimonio territorial. Los paisajes de la agricultura vistos como patrimonio, Boletín de la Asociación de Geógrafos Españoles, 49, pp. 309-334.

Suárez, M. L. \& Vidal-Abarca, M. R. (2000) Aplicación del índice de calidad del bosque de ribera QBR (Munné et al., 1998) a los cauces fluviales de la Cuenca del río Segura, Tecnología del Agua, 201, pp. 33-45.

Suárez, M. L., Vidal-Abarca, M. R., Sánchez-Montoya, M., Alba, J., Álvarez, M., Avilés, J., Bonada, N., Casas, J., Jáimez-Cuellar, P., Munné, A., Pardo, I., Prat, N., Ribadeneira, M., Salinas, J., Toro, M. \& Vivas, S. (2002) Las riberas de los ríos mediterráneos y su calidad: el uso del índice QBR, Limnetica, 21(3-4), pp. $135-148$.

Torroja Miret, E. (1960) Razón y ser de los tipos estructurales (Madrid: Instituto Eduardo Torroja). 